\title{
THE EFFECT OF SOIL PH AND ZEOLITE APPLICATION ON LEAD (PB) IMMOBILIZATION ON CONTAMINATED SOIL
}

Dam Ha Luong Thanh*, Dang Thi Thai Ha

TNU - International School

\begin{tabular}{|c|c|c|}
\hline \multicolumn{2}{|c|}{ ARTICLE INFO } & ABSTRACT \\
\hline Received: & $14 / 4 / 2021$ & Soil application of zeolite has been shown to effectively immobilize \\
\hline Revised: & $12 / 5 / 2021$ & $\begin{array}{l}\text { potentially toxic elements (PTEs). Soil } \mathrm{pH} \text { can also affect PTE availability. } \\
\text { No previous studies have examined the interactive effect of zeolite and soil }\end{array}$ \\
\hline Published: & $20 / 5 / 2021$ & $\mathrm{pH}$ on $\mathrm{Pb}$ immobilization. Therefore, this study investigated the effect of 2 \\
\hline & & kinds of zeolite as natural zeolite (N-Z) and $\mathrm{Mg} / \mathrm{Al} \mathrm{LDH}$ zeolite (LDH-Z) \\
\hline \multicolumn{2}{|l|}{ KEYWORDS } & applied at $3 \mathrm{wt} \%$, under one control experiment (CT1) and 5 soil $\mathrm{pH}$ \\
\hline \multicolumn{2}{|l|}{ Soil contamination } & soil. Results showed that $\mathrm{N}-\mathrm{Z}$ and $\mathrm{LDH}-\mathrm{Z}$ treatments significantly \\
\hline \multicolumn{2}{|l|}{ The exchangeable $\mathrm{Pb}$} & enhanced $\mathrm{Pb}$ stabilization, which could promote $\mathrm{Pb}$ conversion into stable \\
\hline \multicolumn{2}{|l|}{ Immobilization } & chemical fractions. Immobilization of $\mathrm{Pb}$ was enhanced under the soil $\mathrm{pH}$ \\
\hline \multicolumn{2}{|l|}{ Natural zeolite } & of 5.0 with the application of both natural and LDH zeolite, and the figure \\
\hline \multicolumn{2}{|l|}{ LDH zeolite } & $\begin{array}{l}\mathrm{Mg} / \mathrm{Al} \mathrm{LDH} \text { zeolite significantly gave higher rate of immobilizing } \\
\text { exchangeable } \mathrm{Pb} \text { in amended contaminated soil than natural zeolite. The } \\
\text { exchangeable } \mathrm{Pb} \text { in the control experiment was reported at } 86.31 \% \text {; and } \\
\text { this figure decreased to } 45.5 \% \text { and } 37.88 \% \text { after the incubation with natural } \\
\text { zeolite, and } \mathrm{LDH} \text { zeolite respectively. }\end{array}$ \\
\hline
\end{tabular}

\section{ẢNH HƯởNG CỦA PH ĐÁT VÀ VẠT LIỆU ZEOLIT ĐẾN KHẢ NĂNG XỬ LÝ KIM LOẠI NĀNG (CHÌ) TRONG ĐÂTT Ô NHIỄM CHÌ}

\author{
Đàm Hà Lương Thanh*, Đặng Thị Thái Hà
}

Khoa Quốc tế - ĐH Thái Nguyên

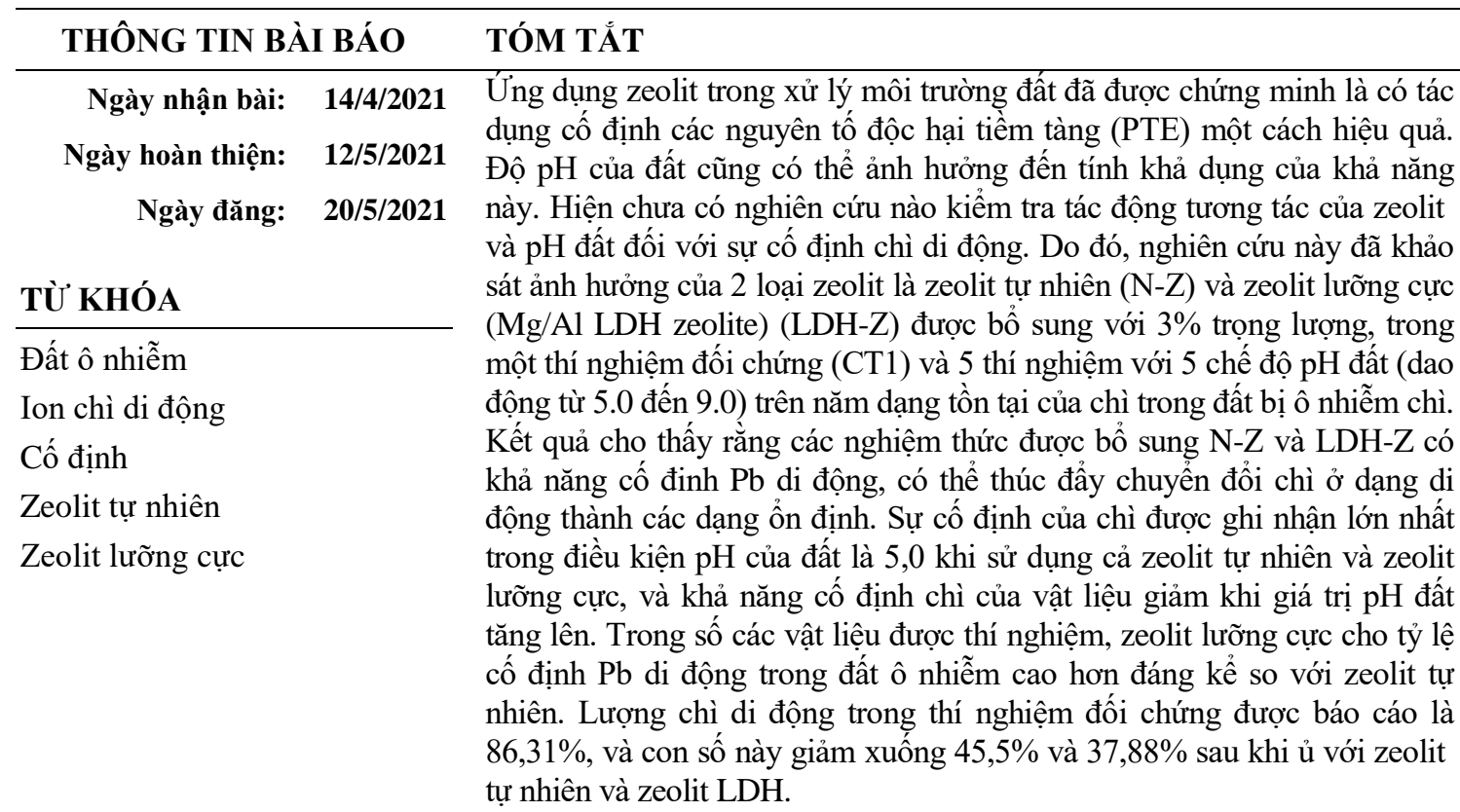

DOI: https://doi.org/10.34238/tnu-jst.4345

\footnotetext{
* Corresponding author. Email: thanhdhl@tnu.edu.vn
} 


\section{Introduction}

Food safety is a global priority for the better human health, however, it is threatened due to toxic heavy metal contamination of agricultural soils [1]. Therefore, the quality of soil must be maintained to agricultural activities. $\mathrm{Pb}$ can be released from mining and plating activities or weathering and biochemical reactions and can cause soil and water pollution. The exchangeable $\mathrm{Pb}$ is one of the most toxic heavy metals with a lethal dose of only $450 \mathrm{mg} / \mathrm{kg}$ of body weight [2].

Recently, lead contamination has become a major issue worldwide. The contamination of the exchangeable $\mathrm{Pb}$ in soil is one of the concerning environmental problems. The exchangeable $\mathrm{Pb}$ in soil not only influences the surrounding environment but also accumulate to a risk for human health. Lead poisoning has been recognized as a serious health problem all over the world for decades. Human can be exposed to the exchangeable $\mathrm{Pb}$ by eating $\mathrm{Pb}$-contaminated food [3]. It can lead to serious problems, such as liver damage, pulmonary congestion [2], teratogenicity and mutagenicity. The effect of lead also permanently reduces children's cognitive abilities, even when they are exposed to extremely low level [4] Therefore, it is necessary to remove the exchangeable $\mathrm{Pb}$ from contaminated soils, especially in agricultural soils.

In Vietnam, lead exposure occurs in many localities to a variety of different causes. These include mental lead mining [5], industrial wastewater from factories and industrial parks, municipal waste, abuse of pesticide chemicals [6] production of batteries, and lead recycling activities. Previous study conducted in Dong Hy district showed very high contents of $\mathrm{Pb}$ in soil sample $(1,100-13,000 \mathrm{mg} / \mathrm{kg})$, exceeding the safe level from 15.7 to 185.7 times [7]. These indexes could directly impact to environment and people living surrounding the contaminated areas.

Therefore, the monitoring and remediation of $\mathrm{Pb}$ and heavy mental contamination in Vietnam are of great concern of local people, authorities, and scientists. Several methods have been applied to remediate the exchangeable heavy mental from contaminated soil and water, including chemical reduction, precipitation, biological remediation (bioremediation or phytoremediation) and physical adsorption [8], [9]. Among them, adsorption method is generally considered an effective way for immobilization of the exchangeable heavy mental due to its simple, flexible operation, effectiveness and low cost [6]. The exchangeable $\mathrm{Pb}$ is immobilized by many adsorbents, such as natural minerals (sepiolite, montmorillonite, and attapulgite) [9], synthetic materials $\left(\mathrm{FeS}_{2}\right.$, rice-straw biochar and mixed adsorption materials [10], [11].

Among many adsorbents, mineral materials have been used widely [10]. Because of large specific surface areas, unique porous channel structures, numerous active groups and negative charges, mineral materials become effective adsorbents for the immobilization of heavy metal ions in soil [12]. Zeolite is one of crystalline aluminosilicates with high specific surface area and ion-exchange capacity [13], [14] and have ability to entrap metals into their pores and to absorb metals on their surface, therefore, it may be applied as a promising remediation material to remove the exchangeable $\mathrm{Pb}$ in contaminated soils [15], [16].

In this study, natural zeolite and $\mathrm{Ma} / \mathrm{Al} \mathrm{LDH}$ zeolite is investigated for aiming the influence of soil $\mathrm{pH}$ and the absorbent application on immobilizing exchangeable $\mathrm{Pb}$ in amended contaminated soil.

\section{Materials and methods}

\subsection{Soil preparation and adsorbent}

Fresh soil was collected at depth of $0-50 \mathrm{~cm}$ of the hill at the Experimental Farm of University of Agriculture and Forestry - Thai Nguyen University, Thai Nguyen province, Vietnam. The collecting site is located at natural land area without agricultural cultivation. Collected soil was air-dried for one week before sieving through a size of less than $2 \mathrm{~mm}$. All these soil processing procedures were carried out in laboratory and using for further experiments. 
Natural zeolite used for the experiments with size of less than $1 \mathrm{~mm}$ was purchased from Nito Funka Kogyo K.K. Company, Japan. Mg/Al LDH zeolite used for the experiments with size of less than $1 \mathrm{~nm}$ was produced by Thai Nguyen University of Science.

\subsection{Soil incubation experiments}

Fresh soil, was contaminated with concentration of $50 \mathrm{mg} / \mathrm{kg}$ of the exchangeable $\mathrm{Pb}$, which was called contaminated soil. The contaminated soil was then used to determine the influence of soil $\mathrm{pH}$ value (5-9) for immobilization of the exchangeable $\mathrm{Pb}$ after 30 days of incubation. In general, the exchangeable form of heavy mental, especially $\mathrm{Pb}$, existed at the highest concentration in the acidic environment, hence, the neutral and alkaline condition with $\mathrm{pH}$ ranging from 5 to 9 was selected for this research.

Unamend soils were used as control treatment in the experiments. There were three replications in each experiment. The experiment was set up as follows: $50 \mathrm{~g}$ of control treatments $(\mathrm{Pb}$ contaminated soil $(\mathrm{CT} 1))$; and $50 \mathrm{~g}$ of $\mathrm{Pb}$ contaminated soil $(50 \mathrm{mg} / \mathrm{kg})$ with adjusted $\mathrm{pH}$ of 5, 6, 7, 8 and 9, plus $3 \%$ natural zeolite, LDH zeolite, respectively. This experimental condition as zeolite application rate, incubation time were selected as previous studies have shown that at 3\% application rate, and after 30 days of incubation heavy metals are able to be immobilized. Soil $\mathrm{pH}$ was adjusted by using $\mathrm{Ca}(\mathrm{OH})_{2}$ solution. All samples were adjusted the soil moisture of $75-80 \%$, put in sealed plastic bottles (inner diameter, height and wide of $5.0 \mathrm{~cm}, 18.0 \mathrm{~cm}$ and $5.0 \mathrm{~cm}$, respectively) and incubated for 30 days in an indoor environment with a temperature of $25^{\circ} \mathrm{C}$. Soil samples were collected at the endpoint of incubation, then dried at $105{ }^{\circ} \mathrm{C}$ for $2 \mathrm{~h}$ before analyzing. All the process of soil incubation experiments was conducted in the laboratory of Department of Natural Resources and Environment, University of Science, Thai Nguyen University.

\subsection{Soil analysis}

The method for determining soil pH followed Bian et al. [17]. Organic carbon (OC) in soil and amendments was measured using the Walkley-Black titration method. Soil texture (sand, limon and clay) was analyzed according to TCVN 8567:2010 [18]. Five fraction analysis of $\mathrm{Pb}$ in soil was conducted by sequential extraction procedure developed by Tessier et al. (1979) [19] and modified by M. Nguyen Ngoc et al.[20], soil can be apportioned in five phases: exchangeable heavy metals (Fraction 1, F1), carbonate-bound (Fraction 2, F2), Fe-Mn oxides bound (Fraction $3, \mathrm{~F} 3$ ), complexation of heavy metals with organic matters (Fraction 4, F4) and residual heavy metals (Fraction 5, F5).

The morphology of examined materials as natural and LDH zeolite was examined using an energy dispersive X-ray spectroscopy equipped with EDS and SEM system (HITACHI S-4800), Determination of the surface area and the porous structure was conducted using BrunauerEmmett-Teller (BET - BET, Builder, SSA-4300).

All the process of analyzing soil was conducted in the laboratory of Department of Natural Resources and Environment, University of Science, Thai Nguyen University.

\section{Results}

\subsection{Characteristics of the study soil and amendments}

\subsubsection{Characteristics of the initial soil}

The characteristics of the experimental soil are presented in Table 1. The proportion of sand, limon and clay in the soil were $55.16 \%, 23.83 \%$ and $21.02 \%$, respectively. The soil $\mathrm{pH}$ of 4.93 is suitable for agricultural development. The concentrations of total $\mathrm{Pb}$ in the soil were very low at $1.92 \mathrm{mg} / \mathrm{kg}$. The exchangeable form of $\mathrm{Pb}$ was also very low in concentrations at $0.21 \mathrm{mg} / \mathrm{kg}$. This information of soil indicated that the soil is fresh. 
Table 1. Physicochemical properties of the initial soil

\begin{tabular}{lll}
\hline Properties & Unit & Soil \\
\hline Sand & $\%$ & $55.16 \pm 1.51$ \\
Limon & $\%$ & $23.82 \pm 1.25$ \\
Clay & $\%$ & $21.02 \pm 1.50$ \\
$\mathrm{pH}_{(\mathrm{H} 2 \mathrm{O})}$ & $\%$ & $4.93 \pm 0.2$ \\
$\mathrm{OC}$ & $\mathrm{mg} / \mathrm{kg}$ & $2.03 \pm 0.01$ \\
Total $\mathrm{Pb}$ & $\mathrm{mg} / \mathrm{kg}$ & $0.21 \pm 0.004$ \\
Exchangeable $\mathrm{Pb}$ & & \\
\hline
\end{tabular}

Remark: mean \pm S.D., $\mathrm{n}=3$.

\subsubsection{Characteristics of zeolite}

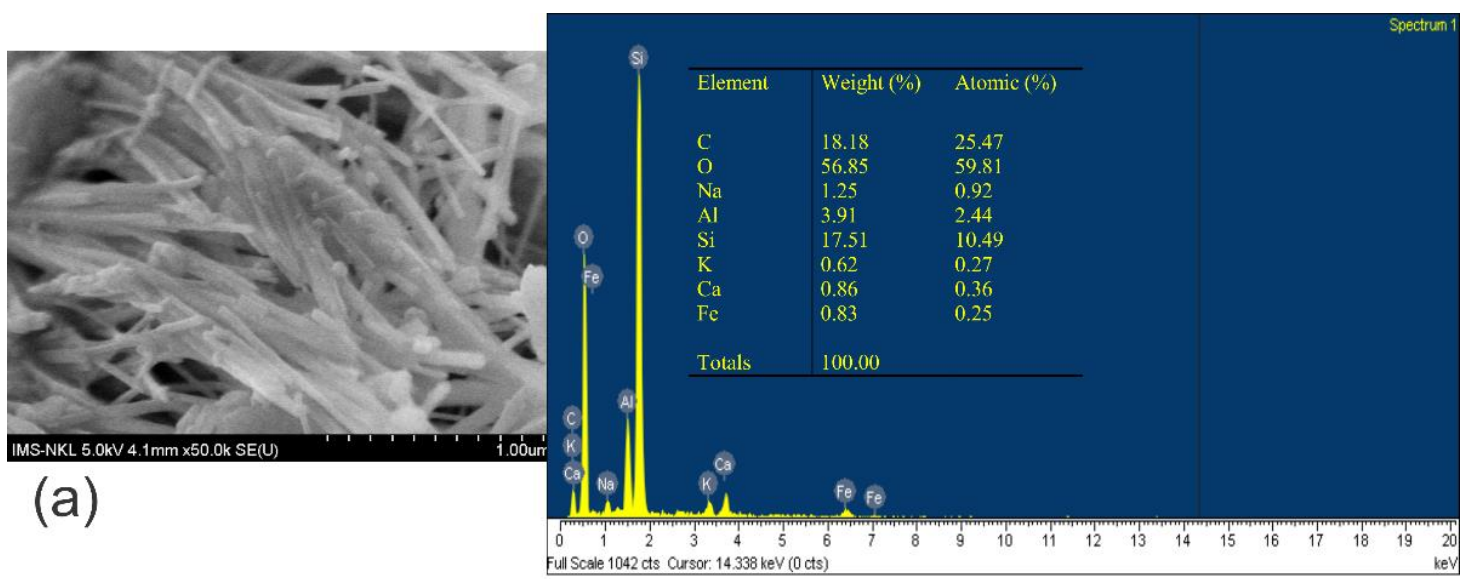

(b)

Figure 1. SEM images (a) and EDX (b) of zeolite

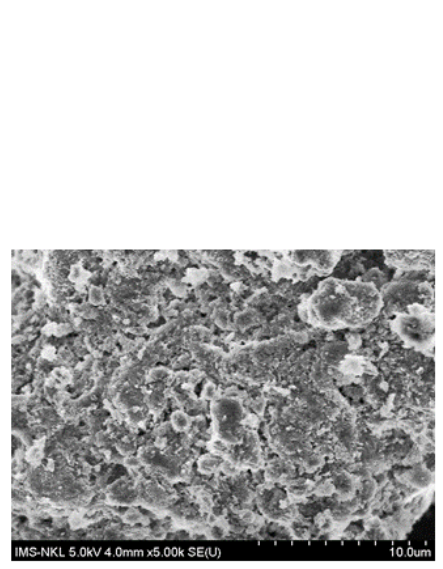

(a)

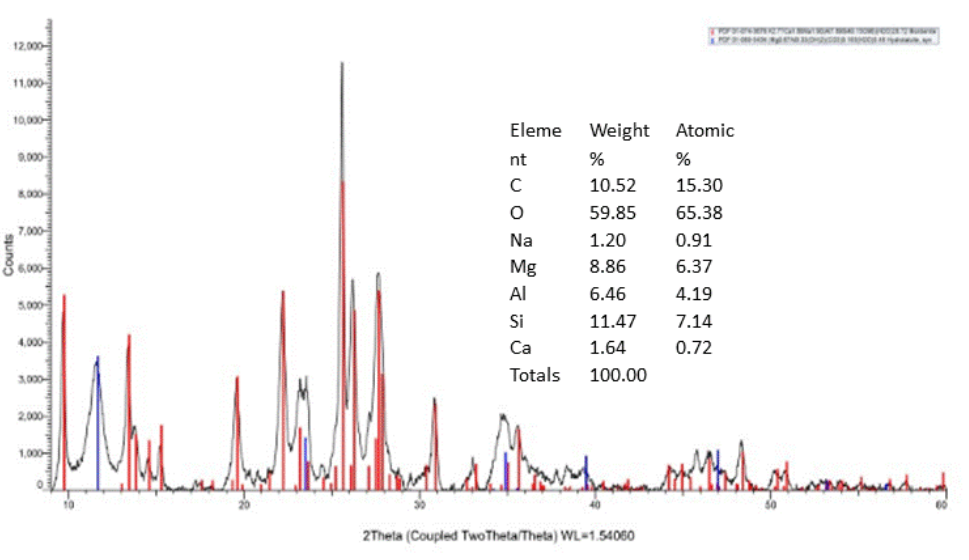

(b)

Figure 2. SEM images (a) and EDX (b) of Mg/Al LDH zeolite

As the results, natural zeolite had specific surface area of $3.7930 \mathrm{~m}^{2} / \mathrm{g}$ and the average pore volume was $0.010824 \mathrm{~cm}^{3} / \mathrm{g}$ and pore size of $11.6766 \mathrm{~nm}$. The results of EDX analysis revealed that the weight proportions of elements from natural zeolite is composed of $\mathrm{C}(18.18 \%), \mathrm{O}$ (56.85\%), Na (1.25\%), Al (3.91\%), Si (17.51\%), K (0.62\%), Ca (0.86\%) and Fe (0.83\%) (Figure 
1b). Figure 1a indicates data about SEM image of zeolite with a uniform particle and porous structure. Most particles are rod shape and some particles with a quasi-cubic shape. Additionally, the result also illustrates that the material was porous. The EDX analysis data also indicated that most elements of natural zeolite exist in $\mathrm{CaCO}_{3}, \mathrm{SiO}_{2}, \mathrm{Al}_{2} \mathrm{O}_{3}$ and other forms.

The texture of $\mathrm{Mg} / \mathrm{Al} \mathrm{LDH}$ zeolite was shown under the Brunauer-Emmett-Teller (BET) results with specific surface area of $21 \mathrm{~m}^{2} / \mathrm{g}$ and the average pore volume was $0.19 \mathrm{~cm}^{3} / \mathrm{g}$ and pore size of $13 \mathrm{~nm}$. The results of EDX analysis revealed that the weight proportions of elements from natural zeolite is composed of $\mathrm{C}(10.52 \%), \mathrm{O}(59.85 \%), \mathrm{Na}(1.2 \%), \mathrm{Al}(6.46 \%), \mathrm{Si}$ (11.47\%), and $\mathrm{Ca}(1.64 \%)$ (Figure 2b). Figure 2a indicates data about SEM image of LDH zeolite, most particles exhibit a typical spheroidal rose-like morphology. Additionally, the result also illustrates that the material was porous.

\subsection{Effect of soil $p H$ on immobilization of the exchangeable Pb}

Table 2. The effects of soil $\mathrm{pH}$ to immobilization of exchangeable Pb in contaminated soil

\begin{tabular}{|c|c|c|c|c|c|c|}
\hline \multirow{2}{*}{\multicolumn{2}{|c|}{ pH }} & F1 & F2 & F3 & F4 & F5 \\
\hline & & \multicolumn{5}{|c|}{$\mathrm{Mg} / \mathrm{kg}$} \\
\hline \multirow{6}{*}{$\begin{array}{l}\text { Natural } \\
\text { zeolite }\end{array}$} & $\begin{array}{c}\text { CT1 } \\
\text { (control) }\end{array}$ & $25.03 \pm 3.88^{\mathrm{b}}$ & $0.33 \pm 0.01^{\mathrm{a}}$ & $1.26 \pm 0.07^{\mathrm{a}}$ & $1.25 \pm 0.61^{\mathrm{a}}$ & $1.33 \pm 0.13^{\mathrm{a}}$ \\
\hline & 5.0 & $18.09 \pm 0.77^{\mathrm{a}}$ & $1.62 \pm 0.1^{\mathrm{b}}$ & $6.62 \pm 0.07^{\mathrm{c}}$ & $6.49 \pm 0.24^{b}$ & $6.86 \pm 0.61^{b}$ \\
\hline & 6.0 & $18.35 \pm 0.74^{\mathrm{a}}$ & $1.56 \pm 0.14^{\mathrm{b}}$ & $6.23 \pm 0.03^{\mathrm{b}}$ & $6.20 \pm 0.07^{\mathrm{b}}$ & $6.81 \pm 0.46^{b}$ \\
\hline & 7.0 & $23.31 \pm 4.25^{\mathrm{ab}}$ & $1.66 \pm 0.08^{\mathrm{b}}$ & $6.15 \pm 0.25^{b}$ & $6.24 \pm 0.28^{b}$ & $6.71 \pm 0.57^{b}$ \\
\hline & 8.0 & $26.76 \pm 3.88^{\mathrm{b}}$ & $1.59 \pm 0.09^{\mathrm{b}}$ & $6.6 \pm 0.2^{c}$ & $6.54 \pm 0.25^{\mathrm{b}}$ & $7.04 \pm 0.46^{\mathrm{b}}$ \\
\hline & 9.0 & $26.33 \pm 4.70^{\mathrm{d}}$ & $1.58 \pm 0.1^{\mathrm{b}}$ & $6.43 \pm 0.21^{b c}$ & $6.49 \pm 0.16^{\mathrm{b}}$ & $7.15 \pm 0.6^{\mathrm{b}}$ \\
\hline \multirow{6}{*}{ LDH zeolite } & $\begin{array}{c}\text { CT1 } \\
\text { (control) }\end{array}$ & $25.03 \pm 3.88^{\mathrm{b}}$ & $0.33 \pm 0.01^{\mathrm{a}}$ & $1.26 \pm 0.07^{\mathrm{a}}$ & $1.25 \pm 0.06^{\mathrm{a}}$ & $1.33 \pm 0.13^{\mathrm{a}}$ \\
\hline & 5.0 & $9.92 \pm 0.44^{\mathrm{a}}$ & $1.53 \pm 0.05^{\mathrm{d}}$ & $5.42 \pm 0.18^{\mathrm{e}}$ & $5.18 \pm 0.26^{\mathrm{e}}$ & $4.14 \pm 0.14^{\mathrm{d}}$ \\
\hline & 6.0 & $13.47 \pm 0.31^{\mathrm{b}}$ & $1.35 \pm 0.06^{\mathrm{c}}$ & $4.58 \pm 0.19^{\mathrm{d}}$ & $4.23 \pm 0.27^{\mathrm{d}}$ & $2.37 \pm 0.1^{\mathrm{c}}$ \\
\hline & 7.0 & $16.77 \pm 0.4^{\mathrm{c}}$ & $1.4 \pm 0.55^{\mathrm{d}}$ & $2.93 \pm 0.1^{\mathrm{c}}$ & $3.45 \pm 0.1^{\mathrm{c}}$ & $1.63 \pm 0.2^{\mathrm{ab}}$ \\
\hline & 8.0 & $19.15 \pm 0.31^{\mathrm{d}}$ & $1.09 \pm 0.045^{\mathrm{b}}$ & $2.47 \pm 0.62^{\mathrm{b}}$ & $2.16 \pm 0.11^{\mathrm{b}}$ & $1.66 \pm 0.21^{b}$ \\
\hline & 9.0 & $19.01 \pm 0.68^{\mathrm{d}}$ & $1.0 \pm 0.06^{\mathrm{c}}$ & $3.0 \pm 0.15^{\mathrm{b}}$ & $2.0 \pm 1.52^{\mathrm{b}}$ & $1.0 \pm 0.14^{\mathrm{ab}}$ \\
\hline
\end{tabular}

The soil $\mathrm{pH}$ is an important factor that impacts on the immobilization of heavy metal in soil. Table 2 presents the effect of soil $\mathrm{pH}$ (acidic, neutral, and alkaline conditions) on the immobilization of the exchangeable $\mathrm{Pb}$ in contaminated soils by using examined absorbents. The concentration of exchangeable $\mathrm{Pb}$ in fresh soil was very low $(0.21 \mathrm{mg} / \mathrm{kg})$ and have no effect to the results after contaminating the soil. It was mixed $50 \mathrm{mg} / \mathrm{kg}$ of the exchangeable $\mathrm{Pb}$. After 30 days of incubation, the concentration of the exchangeable $\mathrm{Pb}(\mathrm{F} 1)$ was as high at $25.03 \mathrm{mg} / \mathrm{kg}$ in the un-amended soil (CT1), the rest existed in other fractions (F2-F5). The concentration of the exchangeable $\mathrm{Pb}$ decreased after incubated with materials with ratio of $3 \%$ for 30 days. $\mathrm{A}$ decrease in the exchangeable fraction $(\mathrm{F} 1)$ of $\mathrm{Pb}$ was significantly witnessed in amended soils compared with the un-amended soil (control treatment - CT1). The lowest concentration and proportion of the exchangeable $\mathrm{Pb}$ reached $18.09 \mathrm{mg} / \mathrm{kg}$ and 9.92 after incubating with natural zeolite and $\mathrm{Mg} / \mathrm{Al} \mathrm{LDH}$ zeolite respectively, in amended soil at amended treatment with $\mathrm{pH}$ of 5. There was an increase in the concentration and proportion of the exchangeable $\mathrm{Pb}$ when increasing soil $\mathrm{pH}$ in amended soils. Conversely, the concentration and proportion of immobilized $\mathrm{Pb}$ forms in the fraction of the $\mathrm{Fe} / \mathrm{Mn} / \mathrm{Oxide}(\mathrm{F} 2)$, carbonate bound (F3), organic matters (F4) and residual (F5) increased in the amended soils, among which the concentration and proportion of F3 and F4 forms were higher than other forms.

These results indicated that the most exchangeable form of $\mathrm{Pb}$ in amended soils was immobilized in carbonate bound and organic matters when natural zeolite presented in contaminated soils. The suitable condition for immobilization of the exchangeable $\mathrm{Pb}$ reached at 
soil $\mathrm{pH}$ of 5. Soil $\mathrm{pH}$ plays a significant role in the exchangeable form of metals in soils. In general, the exchangeable form of heavy metals exists at acidic soil conditions.

\subsection{Comparison of the absorbents}

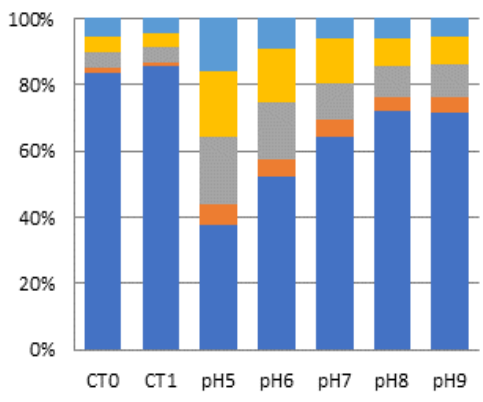

(a)

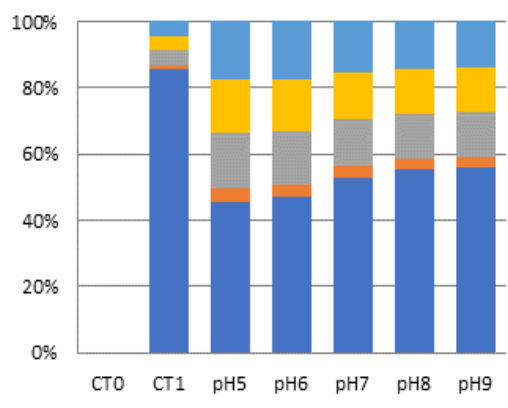

(b)

\author{
Residual \\ Organically complexed \\ Carbonate bound \\ Fe- and Mn- oxide occlude \\ - Exchangable
}

Figure 3. Immobilizing Pb capacity of absorbents at soil $\mathrm{pH}$ of 5.0

(a) Mg/Al LDH zeolite; (b) natural zeolite

In general, heavy mental absorption capacity depends on different factors as discussed throughout this contribution. A careful control of these parameters for different materials is an effective tool to select the suitable application for the right material.

In order to summarize and properly compare, exchangeable $\mathrm{Pb}$ capture capacities of both natural zeolite and $\mathrm{Mg} / \mathrm{Al} \mathrm{LDH}$ zeolite are reported in Figure 3. At soil $\mathrm{pH}$ of 5.0 and the content ratio of $3 \%$, the highest absorption rate was recorded after 30 days of incubation for both examined materials, while rising the value of $\mathrm{pH}$, the exchangeable $\mathrm{Pb}$ in contaminated soil decreased from $86.31 \%$ at un-amended soil treatment to $45.6 \%$ and $37.88 \%$ after incubation of 30 days with natural zeolite and $\mathrm{Mg} / \mathrm{Al} \mathrm{LDH}$ zeolite respectively. Hence, $\mathrm{Mg} / \mathrm{Al} \mathrm{LDH}$ zeolite had higher potential absorption than natural zeolite. This higher rate can be explained by the difference in texture of materials, especially the pore size, pore volume and surface area. While LDH zeolite had a surface area of $21 \mathrm{~m}^{2} / \mathrm{g}$, pore volume of $0.19 \mathrm{~cm}^{3} / \mathrm{g}$, and pore size of $13 \mathrm{~nm}$, these figures of natural zeolite only reached at $3.793 \mathrm{~m}^{2} / \mathrm{g}, 0.0108 \mathrm{~cm}^{3} / \mathrm{g}$, and $11.67 \mathrm{~nm}$.

\section{Conclusion}

The present study used natural zeolite and $\mathrm{Mg} / \mathrm{Al} \mathrm{LDH}$ zeolite to examine the capacity for immobilization of the exchangeable $\mathrm{Pb}$ in contaminated soils with the effect of soil $\mathrm{pH}$. The results indicated that soil $\mathrm{pH}$ of 5.0 and the content ratio of $3 \%$ for both materials were suitable for immobilization of the exchangeable $\mathrm{Pb}$ after 30 days of incubation. The exchangeable $\mathrm{Pb}$ in contaminated soil decreased from $86.31 \%$ at un-amended soil treatment to $45.6 \%$ and $37.88 \%$ after incubation of 30 days with natural zeolite and $\mathrm{Md} / \mathrm{Al} \mathrm{LDH}$ zeolite respectively. The exchangeable form of $\mathrm{Pb}$ was adsorbed by natural zeolite and $\mathrm{LDH}$ zeolite, then became the immobilization forms of carbonate bound (F3) and organic matters (F4) with 16.88\%; $20.7 \%$ and $16.35 \%$; $19.77 \%$, compared to $4.34 \%$ and $4.31 \%$ respectively in fresh soil. There was a small amount of the exchangeable $\mathrm{Pb}$ that bind with the $\mathrm{Fe} / \mathrm{Mn} / \mathrm{Oxide}(\mathrm{F} 2)$. The increase in soil $\mathrm{pH}$ led to the less effective of both materials as natural zeolite and $\mathrm{Mg} / \mathrm{Al} \mathrm{LDH}$ zeolite. The potential mechanisms for stabilizing exchangeable $\mathrm{Pb}$ in amended contaminated soils were regarded as ion exchange. At the experimental condition of soil $\mathrm{pH}$ of 5, and 3\% application rate of materials, $\mathrm{Mg} / \mathrm{Al} \mathrm{LDH}$ zeolite witnessed a higher rate of absorbing exchangeable $\mathrm{Pb}$ than natural zeolite did, which can be explained as the larger surface area, pore volume, and pore size of LDH zeolite in comparison with those figures of natural zeolite. 


\section{REFERENCES}

[1] G. M. Gadd, "Metals, minerals, and microbes: Geomicrobiology and bioremediation" Microbiology, vol. 156, pp. 609-643, 2010.

[2] B. J. Alloway, Heavy metals in soils. Blackie, London, 1990.

[3] M. I. Gonzalez-Martin, I. Revilla, E. V. Betances-Salcedo, and A. M. Vivar-Quintana, "Pesticide residues and heavy mental in commercially processed propolies," Microchemical Journal, vol. 143, p. 423-429, 2018.

[4] B. J. Alloway and D. C. Ayres, Chemical Principles of Environmental Pollution, Blackie Academic \& Professional, London, 1993.

[5] R. D. Reeves, and R.R. Brooks, "Hyperaccumulation of lead and zinc by two metallophytes from a mining area in Central Europe," Environment Pollution, vol. 31, pp. 277-287, 1983.

[6] X. Wan, M. Lei, and T. Chen, "Cost-benefit calculation of phytoremediation technology for heavymetal-contaminated soil," Science of the Total Environment. , vol. 563-564, pp. 796-802, 2016.

[7] MONRE (Ministry of Natural Resources and Environment of Vietnam), National State of Environment 2008: Vietnam Craft Village Environment, Vietnam Ministry of Natural Resources and Environment: Hanoi, Vietnam, 2008.

[8] U. Förstner, "Land Contamination by Metals: Global Scope and Magnitude of Problem," in Metal Speciation and Contamination of Soil, H. E. Allen, C. P. Huang, G. W. Bailey, E. R. Bowers, Eds. CRC Press: Boca Raton, FL, USA, 1995, pp. 1-33.

[9] G. W. Brummer, and U. Herms, "Influence of soil reaction and organic matter on solubility of heavy metals in soils," in Effects of accumulation of air pollutants in forest ecosystems, D. Reidel publishing company, Dordrecht, Germany, 1983, pp. 233 - 243,.

[10] B. B. Heike, "Adsorption of heavy metal ions on soils and soils constituents," Journal of Colloid and Interface Science, vol. 277, pp. 1-18, 2004.

[11] P. A. Iglesias, B. Rubio, and F. Vilas, "Pollution in intertidal sediments of San Simon Bay (Inner Ria de Vigo, NW of Spain): total heavy metal concentrations and speciation," Marine Pollution Bulletin, vol. 46, pp. 491-521, 2003.

[12] H. Akcay, A. Oguz, and C. Karapire, "Study of heavy metal pollution and speciation on Buyak Menderes and Gediz river sediments," Water Research, vol.37, pp.813-822, 2003.

[13] J. Zerbe, "Speciation of Heavy Metals in Bottom Sediments of Lakes," Polish Journal of Environmental Studies, vol. 8, no. 5, pp. 331-339, 1999.

[14] C. K. Yap, and A. Ismail, "Correlations between speciation of $\mathrm{Cd}, \mathrm{Cu}, \mathrm{Pb}$, and $\mathrm{Zn}$ in sediment and their concentrations in total soft tissue of green-lipped mussel Perna viridis from the west coast of Peninsular Malaysia," Environment International, vol. 28, pp. 117-126, 2002.

[15] H. Ren, J. Jiang, D. Wu, Z. Gao, Y. Sun, and C. Luo, "Selective Adsorption of Pb(II) and Cr(VI) by Surfactant-Modified and Unmodified Natural Zeolites: A Comparative Study on Kinetics," Equilibrium, and Mechanism. Water, Air, and Soil Pollution, vol. 227, pp.101-122, 2016.

[16] K. Mlekodaj, K. Tarach, J. Datka, K. Góra-Marek, and W. Makowski, "Porosity and accessibility of acid sites in desilicated ZSM-5 zeolites studied using adsorption of probe molecules," Microporous and Mesoporous Materials, vol. 183, pp.54-61, 2014.

[17] R. Bian, J. Stephen, C. Liqiang, P. Genxing, et al, "A three-year experiment confirms continuous immobilization of cadmium and lead in contaminated paddy field with biochar amendment", Journal of Hazardous Materials, vol. 272, pp. 121-128, 2014.

[18] Ministry of Science and Technology, Soil quality - Method for determination of particle size distribution, 2007.

[19] A. Tessier, C. Campbell, and M. Bisson, "Sequential extraction procedure for speciation of particulate trace metals," Analytical Chemistry., vol. 51, pp. 8-51, 1979.

[20] M. N. Ngoc, S. Dultz, and J. Kasbohm, "Simulation of retention and transport of copper, lead and zinc in a paddy soil of the Red River Delta, Vietnam," Agriculture, Ecosystems \& Environment, vol. 129, pp. 8-16, 2009. 